\section{Humate-based Biostimulants Affect Early Post-transplant Root Growth and Sapflow of Balled and Burlapped Red Maple}

\author{
Matt Kelting ${ }^{1}$, J. Roger Harris ${ }^{2}$, and Jody Fanelli ${ }^{3}$ \\ Virginia Polytechnic Institute and State University, Department of Horticulture, \\ Blacksburg, VA 24061
}

\section{Bonnie Appleton ${ }^{4}$ \\ Hampton Roads Agricultural Research and Extension Center, 1444 Diamond Springs Road, Virginia Beach, VA 23455}

Additional index words. Acer rubrum, humic acid, rhizotron, root length

\begin{abstract}
Application of biostimulants, humate-based products marketed as aids to plant establishment, may increase early post-transplant root growth and water uptake of landscape trees. We tested three distinct types of biostimulants on root growth and sapflow of balled and burlapped red maple (Acer rubrum L. 'Franksred') trees. Treatments included: humate, 1) as a wettable powder formulation, applied as a soil drench; 2) as a liquid formulation to which various purported root growth-promoting additives had been added, also applied as a soil drench; 3) as a dry granular formulation, applied as a topdress; and 4) a nontreated control. Root growth was monitored through single-tree rhizotrons, and sap flow was measured with a heat balance sapflow system. Roots were first observed in the rhizotron windows 38 days after planting. No biostimulant-treated trees had more root length than nontreated controls, and the two soil drench treatments had the lowest root length throughout the 20 weeks of post-transplant observation. All biostimulants increased sapflow.
\end{abstract}

Reduced post-transplant growth (transplant shock) is primarily a result of plant water stress caused by root loss at harvest (Haase and Rose, 1993). Less than $10 \%$ of the original tree root length may be retained upon transplanting 3-year-old field-grown landscape trees (Gilman, 1988). Rapid root regeneration is vital for restoration of full nutrient and water absorption capability, thereby increasing the chance for survival.

Biostimulants, humate-based products described as "non-nutritional products that may reduce fertilizer use and increase yield and resistance to water and temperature stress" (Russo and Berlyn, 1990), have increased root growth in a number of species (Poincelot, 1993; Reynolds et al., 1995; Russo and Berlyn, 1990; Sanders et al., 1990). Biostimulants may also include vitamins (e.g., thiamine) or other organic materials (e.g., seaweed extracts). Auxins and cytokinins in seaweed extracts may stimulate growth (Crouch et al., 1992). Humic materials (humin, humate, fulvic acid) may increase root growth in a manner similar

\footnotetext{
Received for publication 5 June 1997. Accepted for publication 30 Sept. 1997. Use of trade names does not imply endorsement or criticism of the products named or similar ones not named. The cost of publishing this paper was defrayed in part by the payment of page charges. Under postal regulations, this paper therefore must be hereby marked advertisement solely to indicate this fact.

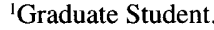

${ }^{2}$ Assistant Professor; to whom correspondence should be addressed.

${ }^{3}$ Research Technician.

${ }^{4}$ Associate Professor.
}

to auxins (O'Donnell, 1973; Tattini et al., 1991). However, biostimulant application is not always beneficial to root growth (Albregts et al., 1988; Elliott and Prevatte, 1996; Laiche, 1991).

Webb and Biggs (1988) reported that application of humates stimulated water uptake by declining citrus trees, possibly as a result of increased root surface area or increased cell permeability (Rauthan and Schnitzer, 1981). Information on the effect of biostimulants on the establishment of landscape trees, transplanted balled and burlapped, is limited. Therefore, the objective of our study was to test the effect of different types of biostimulants on early post-transplant root growth and water uptake of balled and burlapped Acer rubrum L. 'Franksred' trees.

\section{Materials and Methods}

Plant material. On 12 Apr. 1996 (before budbreak), sixteen 4-year-old red maple trees were harvested from established nursery beds at the Virginia Tech Urban Horticulture Center, Blacksburg, Va. (USDA hardiness zone $6 a)$. Mean height and stem diameter $(10 \mathrm{~cm}$ above soil) (SE of mean in parentheses) were $2.5(0.08) \mathrm{m}$ and $2.4(0.08) \mathrm{cm}$, respectively. Soil type was a Groseclose silt loam (clayey, mixed, mesic Typic Hapludults) with $\mathrm{pH}$ 6.2. Trees were hand dug, harvested with $35-\mathrm{cm}-$ diameter rootballs according to industry standards (American Association of Nurserymen, 1996), wrapped in burlap, and planted in single-tree root observation compartments (rhizotrons, described below) $1 \mathrm{~d}$ after harvest. Rootballs were about $5 \mathrm{~cm}$ from the rhizotron windows. The planting backfill was a 1 sand : 1 peat mixture $(\mathrm{v} / \mathrm{v})$, and all trees were fertilized at planting with encapsulated slow-release fertilizer $(18 \mathrm{~N}-2.6 \mathrm{P}-9.9 \mathrm{~K}$; The Scotts Co., Maryville, Ohio) at a rate of $\mathrm{N}$ at $19.4 \mathrm{~g} /$ tree. All trees were irrigated with a microirrigation system so as to maintain backfill and rootball moisture near field capacity throughout the experiment.

Treatments. Treatments were randomly assigned on 16 Apr. 1996 ( 3 d after planting) as: 1) control (no biostimulant); 2) WP humate (a wettable powder formulation, no additives); 3) liquid humate+ (a proprietary liquid mixture of humate, kelp extract, thiamine, and intermediate "metabolites"); and 4) granular humate (a dry granular formulation, no additives). WP humate (Menefee Humate WSP, Earthgreen Products, Dallas, Tex.) was mixed with $\mathrm{H}_{2} \mathrm{O}\left(14 \mathrm{mg} \cdot \mathrm{L}^{-1}\right)$ and applied to the surface of the rootball as a soil drench at $2.3 \mathrm{~L}$ solution/tree. Liquid humate+ (Roots, Roots, New Haven, Conn.) was also mixed with wa$\operatorname{ter}\left(8 \mathrm{~mL} \cdot \mathrm{L}^{-1}\right)$ and applied to the surface of the rootball as a soil drench at $11.3 \mathrm{~L}$ solution/tree. Granular humate (Earthgreen Products, Dallas, Texas) was scattered evenly over the surface of the rhizotron backfill and rootball (dry topdressing) at $6.3 \mathrm{~g} /$ tree. All treatments were replicated four times, and applied at the manufacturer's recommended rate. The experimental design was completely random with four single-tree replications per treatment.

Rhizotrons. Rhizotrons (one rhizotron per tree) were constructed from Keeper-Uppers (KU) (Lerio, Mobile, Ala.), normally used to protect container-grown trees from windthrow and root zone temperature extremes. KUs are flat-topped, bottomless shells, shaped like pyramids, with a square base $(54 \mathrm{~cm}$ length $\times$ $54 \mathrm{~cm}$ width $\times 38 \mathrm{~cm}$ height), and a circular opening ( $43 \mathrm{~cm}$ diameter) in the top for insertion of growing containers (Harris et al., 1996). One, 28-cm-wide $\times 28$-cm-long $\times 6.4$-mmthick, clear polycarbonate sheet (GE Worldwide Manufacturing Sites, Mount Vernon, Ind.) was fastened to the south side of each rhizotron as a window, and a $25 \times 25-\mathrm{cm}$ grid (5-cm increments) was permanently marked on each window. Each window was covered with a 5-cm-thick styrofoam door that served to block light and insulate against temperature extremes. All rhizotrons were painted white and insulated with reflective plastic bubble insulation (Reflectix, Markleville, Ind.) to maintain a backfill temperature comparable to the native soil. Backfill temperatures were monitored every 1 to $3 \mathrm{~d}$ between 1200 to 1400 HR on one rhizotron, with thermocouple junctions placed at $20 \mathrm{~cm}$ depth and about $1 \mathrm{~cm}$ from the rhizotron window. Soil temperatures were also monitored at $20 \mathrm{~cm}$ depth in adjacent native soil. Rhizotron and soil temperatures were similar and averaged $19.5{ }^{\circ} \mathrm{C}$ for the duration of the experiment.

Measurement. Root growth against the rhizotron windows was photographed weekly ( $35 \mathrm{~mm}$ slides), beginning when the roots were first detected on 20 May and ending 29 Aug. 1996. Slides were digitized (Scanmaker 35t; Microtek Intl., Taiwan, R.O.C.) and root 
backfill contrast was computer-enhanced (Adobe Photoshop, ver. 3.0; Adobe Systems, Mountain View, Calif.). Root length was determined using the line intersect method first developed by Newman (1966), then modified by Marsh (1971) and Tennant (1975). Root : line intersections were counted manually in image measurement software (SigmaScan/Image, ver. 1.2; Jandel Scientific, San Rafael, Calif.). At the conclusion of the experiment on 26 Sept. 1996, all roots outside the original root ball were harvested, dried to a constant mass at $70^{\circ} \mathrm{C}$, and weighed.

Two trees were randomly selected in each treatment, and water uptake was determined by stem sapflow measurements monitored at three different periods after transplanting: 1) 2 May to 15 May 1996; 2) 10 June to 16 June 1996; and 3) 27 June to 10 July 1996. Sapflow was measured with a heat-balance sapflow system (Flow32-AO Sap Flow Measurement System; Dynamax, Houston) (Steinberg et al., 1989). One gauge was fitted to the main trunk of each replicate (all foliage was above the gauge) and sealed with silicone for protection against moisture. Interference from solar radiation was minimized by an insulated collar, a heat shield placed around each gauge, and an aluminum foil wrap from the gauge to the ground. Data were collected with a datalogger (CR10; Campbell Scientific, Logan, Utah) every $60 \mathrm{~s}$, averaged every $15 \mathrm{~min}$, and recorded every $30 \mathrm{~min}$. These rates were then used to calculate mean 24-h sapflow for each measurement period.

Root length data were analyzed by repeated measures multivariate analysis of variance (ANOVA) and single degree of freedom contrasts in the GLM procedure (SAS ver. 6.08; SAS Institute, Cary, N.C.), and plotted over time. Root length observed in the rhizotron windows at time of harvest, dry mass of all roots outside of harvested rootballs, and sapflow data were analyzed using one-way ANOVA procedures. Differences among means were determined by Tukey's HSD at $P \leq$ 0.05 .

\section{Results and Discussion}

Root length. Roots were first observed in the rhizotrons on 20 May 1996, 38 d after planting. Root growth (length increase) was rapid until approximately 10 July 1996, and slow thereafter for all treatments (Fig. 1). Data were therefore partitioned into these two time periods, and each period was analyzed separately.

Treatment effect on root length was significant for both periods, as were all contrasts performed, with the exception of control vs. granular humate for 20 July to 28 Aug. (Fig. 1). For 20 May to 10 July, root length of controls was greatest when contrasted with all other treatments, to granular-humate-treated trees, and to the two soil drench treatments. For 20 July to $28 \mathrm{Aug}$., root length was similar in control and granular humate treatments and least in the liquid humate drench treatments.

At the conclusion of the experiment, no treatment significantly increased root length relative to controls, and granular-humatetreated trees had more root length than did trees treated with the two other biostimulants (Table 1). These data agree with those of Reynolds et al. (1995), who reported that liquid-applied humate reduced growth of 'Chardonnay' grapevines, while granular treatments resulted in improved growth. Other reports also indicate that liquid-applied biostimulants may occasionally have negative effects on root growth (Elliott and Prevatte, 1996; Kelting, 1997). Although root length over time was affected by the treatments in our study, all treatments had similar root dry mass at final harvest (Table 1). Contrary to previous studies involving biostimulants or their individual components (e.g., Mylonas and McCants, 1980; O’Donnell, 1973; Schnitzer and Poapst, 1967; Tattini et al., 1991), we found little benefit in their use to promote post-transplant root growth.

Sapflow. For period one, sapflow rates were greatest for controls and for trees treated with liquid humate+ and lowest for trees treated with WP humate (Table 1). This time period was soon after transplanting, before new roots had developed (Fig. 1). Controls had the shortest root length for period two, when root

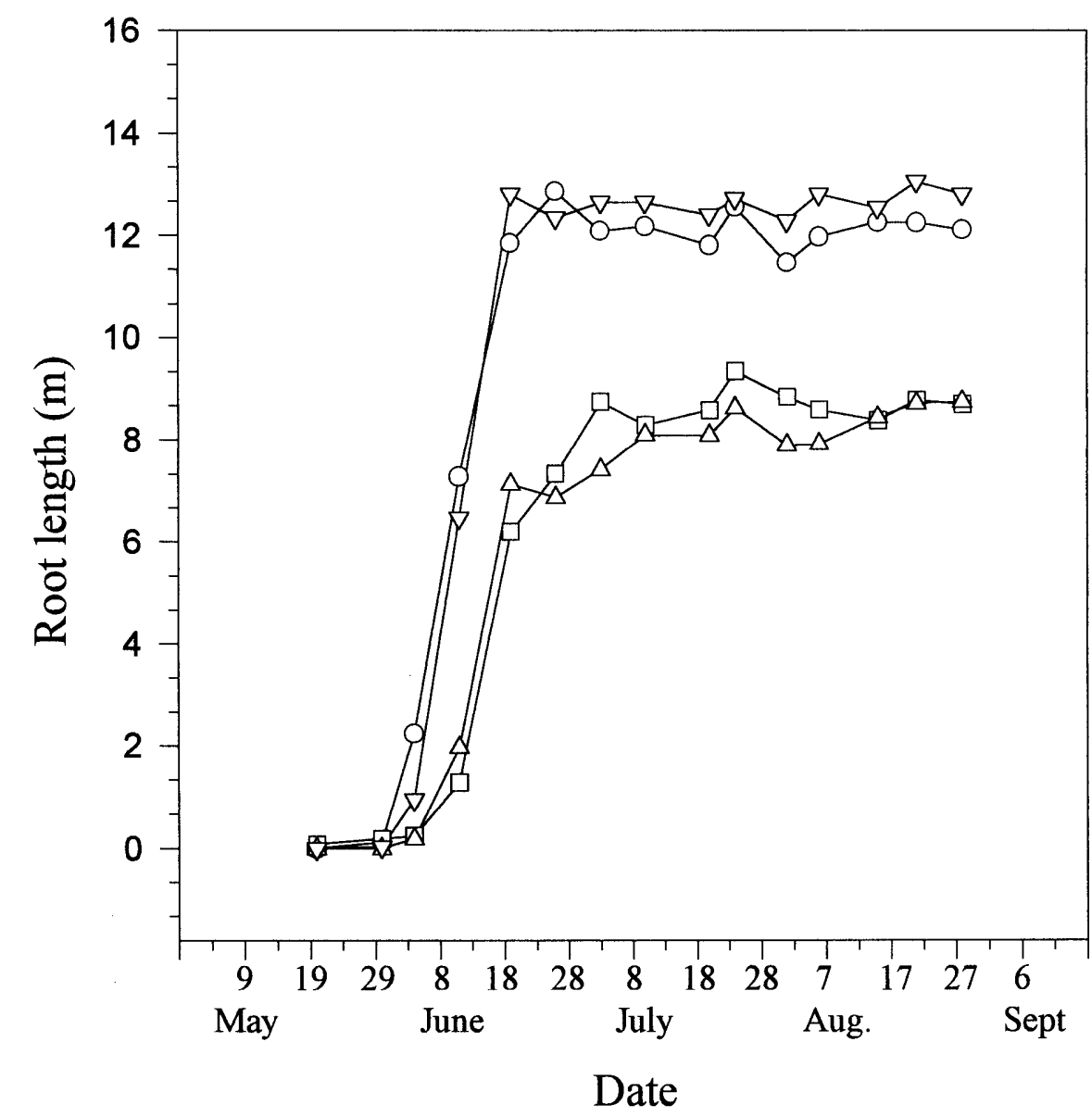

Fig. 1. Early post-transplant root length against rhizotron windows of balled and burlapped 'Franksred' red maple trees, untreated or treated with three biostimulants ( $O$ Control; $\square$ Liquid humate; $\Delta$ Liquid humate+; $\nabla$ Granular humate). $P$ values of single degree of freedom contrasts (Wilks' Lambda multivariate tests, $\mathrm{n}=4$ ) for 20 May to 10 July and for 20 July to 28 Aug. 1996 are: control vs. others $=0.005$ and 0.02 ; control vs. granular humate $=0.05$ and 0.20 ; control vs. soil drenches $=0.03$ and 0.008 , respectively.

Table 1. Effects of humate treatments on final root length against polycarbonate viewing panels of rhizotrons, dry mass of all roots outside of harvested rootball, and sapflow of 'Franksred' red maple trees in 1996.

\begin{tabular}{lccccc}
\hline \hline & Root dry & Final root & \multicolumn{3}{c}{ Sapflow (g/day) } \\
\cline { 5 - 6 } Treatments & ${\text { length }(\mathrm{m})^{\mathrm{z}}}^{\mathrm{n}}$ & mass $(\mathrm{g})^{\mathrm{z}}$ & Period one $^{\mathrm{y}}$ & Period two $^{\mathrm{x}}$ & Period three $^{\mathrm{w}}$ \\
\hline Control & $12.1 \mathrm{ab}^{v}$ & $94.5 \mathrm{a}$ & $11.3 \mathrm{bc}$ & $21.2 \mathrm{c}$ & $40.0 \mathrm{~b}$ \\
WP humate & $8.7 \mathrm{~b}$ & $127.2 \mathrm{a}$ & $7.6 \mathrm{c}$ & $42.0 \mathrm{ab}$ & $58.2 \mathrm{a}$ \\
Liquid humate+ & $8.8 \mathrm{~b}$ & $120.0 \mathrm{a}$ & $18.5 \mathrm{a}$ & $33.4 \mathrm{a}$ & $58.2 \mathrm{a}$ \\
Granular humate & $12.8 \mathrm{a}$ & $133.2 \mathrm{a}$ & $15.0 \mathrm{ab}$ & $44.8 \mathrm{a}$ & $58.0 \mathrm{a}$ \\
\hline
\end{tabular}

${ }^{z_{n}=4}$.

$\mathrm{y}_{2}$ to 15 May, $\mathrm{n}=2$.

${ }^{\mathrm{x}} 10$ to 16 June, $\mathrm{n}=2$.

" 27 to 10 July, $\mathrm{n}=2$.

'Mean separation in columns by Tukey's HSD $(P \leq .05)$. 
growth was accelerating, and also for period three, when root growth slowed dramatically.

These results support others who have reported that biostimulants or their components may increase water uptake (Russo and Berlyn, 1990; Webb and Biggs, 1988). In the present study, root length was not increased by biostimulant treatments, although sapflow was. Increased sapflow may be a result of increased cell membrane permeability as proposed by Rautham and Schnitzer (1981). However, further research is needed to examine the mechanisms of this effect.

Under the conditions of our study, biostimulants did not increase early post-transplant root growth, but they did increase stem sapflow of balled and burlapped red maple. How this may affect growth in the long term has yet to be determined. Trees did not differ visually after 20 weeks of growth, and no differences in height or stem diameter were apparent at the conclusion of the experiment (data not shown). However, trees in our experiment were always well watered. Further experimentation is needed to examine biostimulant influence on tree survival in various post-transplant conditions such as drought.

\section{Literature Cited}

Albregts, E.E., C.M. Howard, and C. Chandler. 1988. Effect of biostimulants on fruiting of strawberry. Proc. Fla. State Hort. Soc. 101:370372.

American Association of Nurserymen. 1996. Ameri- can standard for nursery stock. Amer. Assn. Nurserymen, Washington, D.C.

Crouch, I.J., M.T. Smith, J. Van Staden, M.J. Lewis, and G.V.Hoad. 1992. Identification of auxins in a commercial seaweed concentrate. J. Plant Physiol. 139:590-594.

Elliott, M.L. and M. Prevatte. 1996. Response of 'Tifdwarf' bermuda grass to seaweed-derived biostimulants. HortTechnology 6:261-263.

Gilman, E.F. 1988. Tree root spread in relation to branch dripline and harvestable rootball. HortScience 23:351-353.

Haase, D.L. and R. Rose. 1993. Soil moisture stress induces transplant shock in stored and unstored $2+0$ Douglas-fir seedlings of varying root volumes. For. Sci. 39:275-294.

Harris, J.R., A.X. Niemiera, R.D. Wright, and C.H. Parkerson. 1996. Chemically controlling root escape in pot-in-pot production of river birch and Yoshino cherry. HortTechnology 6:30-34.

Kelting, M.P. 1997. Effects of soil amendments and biostimulants on the post-transplant growth of landscape trees. MS Thesis, Virginia Polytechnic and State Univ., Blacksburg.

Laiche, A.J., Jr. 1991. Evaluation of humic acid and slow release fertilizers on container-grown landscape plants. Res. Rpt. Mississippi Agr. For. Expt. Sta. 16(7):1-3.

Marsh, B. a'B. 1971. Measurements of length in random arrangements of lines (Short communication). J. Appl. Ecol. 8:265-267.

Mylonas, V.A. and C.B. McCants. 1980. Effects of humic and fulvic acids on growth of tobacco. Plant Soil 54:485-490.

Newman, E.I. 1966. A method of estimating the total length of root in a sample. J. Appl. Ecol. 3:139-145.

O'Donnell, R.W. 1973. The auxin-like effects of humic preparations from leonardite. Soil Science 116:106-112.

Poincelot, R.P. 1993. The use of a commercial organic biostimulant for bedding plant production. J. Sustainable Agr. 3:99-110.

Rauthan, B.S. and M. Schnitzer. 1981. Effects of a fulvic acid on the growth and nutrient content of cucumber (Cucumis sativus) plants. Plant Soil 63:491-495.

Reynolds, A.G., D.A. Wardle, B. Drought, and R. Cantwell. 1995. Gro-mate soil amendment improves growth of greenhouse-grown "Chardonnay' grapevines. HortScience 30:539-542.

Russo, R.O. and G. P. Berlyn. 1990. The use of organic biostimulants to help low input sustainable agriculture. J. Sustainable Agr. 1(2):1942.

Sanders, D.C., J.A. Ricotta, and L. Hodges. 1990. Improvement of carrot stands with plant biostimulants and fluid drilling. HortScience 25:181-183.

Schnitzer, M., and P.A. Poapst. 1967. Effects of a soil humic compound on root initiation. Nature 213:598-599.

Steinberg, S., C.H.M. van Bavel, and M.J. McFarland. 1989. A gauge to measure mass flow rate of sap in stems and trunks of woody plants. J. Amer. Soc. Hort. Sci. 114:466-472.

Tattini, M., P. Bertoni, A. Landi, and M.L. Traversi. 1991. Effect of humic acids on growth and biomass partitioning of container-grown olive plants. Acta Hort. 294:75-80.

Tennant, D. 1975. A test of a modified line intersect method of estimating root length (in wheat). $\mathrm{J}$. Ecol. 63:995-1001.

Webb, P.G. and R.H. Biggs. 1988. Effects of humate amended soils on the growth of citrus. Proc. Fla. State Hort. Soc. 101:23-25. 